\title{
The Use of Learning Media with MOODLE Approach to Improve the Quality of Education: A Literature Study
}

\author{
Andika Puspita Sari ${ }^{1}$, Baedhowi ${ }^{1}$, Cicilia Dyah Sulistyaningrum Indrawati ${ }^{1}$ \\ ${ }^{1}$ Universitas Sebelas Maret, Jl. Ir. Sutami No.36A, Jebres, Surakarta, Jawa Tengah, \\ Indonesia
}

\begin{abstract}
This article aimed to find out whether using Moodle approach as a learning medium can improve the quality of education. The method used in this research was literature study. The background of the research was the fact that the rapid development of technology has become a very useful and beneficial means to improve the quality of education so that it would be ironic if it could not be utilized optimally. Based on the result of analyses of the journals about learning media using Moodle, it could be concluded that Moodle could improve the quality of education.
\end{abstract}

Keywords: Learning Media; Moodle; Quality of Education

\section{INTRODUCTION}

Education is a very important matter for a country. One of the countries with the category of low quality in education is Indonesia. Article 31 of the 1945 Constitution states that every citizen has the right to get and to attend basic education and it is government's obligation to be responsible for the finance. However, the fact says that the quality of education in Indonesia is still very low. It can be seen from the position of Indonesia in the world education ranking, a survey result issued by Organization for Economic Co-operation and Development (OECD) released by The Guardian 2016. Indonesia was at number 57 from 65 countries [1]. Other countries with the category of low in terms of educations in 2016 were Argentina (61), Kazakhstan (62), Albania (63) and Kyrgyzstan (68). The low quality of education shows that the goal of education has not been achieved yet. Therefore, efforts to improve the components of learning need to be done.

There are six components of learning, i.e. goal, learning subject, learning material, learning strategy, learning media, and supporting infrastructure [2]. One of the most important components is learning media. Media are means or tools to convey the content or material of learning. Today, media play a very important role in teaching learning process. Media are inseparable parts of learning and teaching process to gain the goal of education [3]. Media are closely related to the development of technology and always develop from time to time. The kind of information-technology that is developing today is internet. The availability of internet network in various countries has given unlimited opportunities if it can be utilized well. However, it has not been used optimally yet. Based on the publication from emarketer.com, Indonesia was ranked sixth among the countries with the highest number of internet users in the world. 
The top ten countries with the highest number of internet users in the world were China, India, United States of America, Brazil, Japan, Indonesia, Russia, Mexico, Nigeria, and Germany. Based on a research by Internet Worlds Stats in 2016, Indonesia was ranked fourth among the countries with the highest number of internet users in Asia. It was because $30.5 \%$ or around 78 million of 250 million of Indonesian population used internet. The utilization of internet in Indonesia was still under China, India, and Japan. In addition, the survey result from the statistic data of Indonesian Internet Service Provider Association stated that the number of internet users in Indonesia reached 132.7 million users or around $51.5 \%$ of Indonesia's 256.2 millions of population. Java Island had the highest number of users with the total users of 86.339 .350 user or around $65 \%$ of total users. The second-ranked was Sumatera Island with the total users 20.752.185 or around $15.7 \%$, Sulawesi Island with the total users of 8.454 .592 or around $6.3 \%$, Sulawesi Island with the total users of 7.685 .992 or around 5.3\% and finally Bali and Nusa with the total users of 6.148 .796 or around $4.7 \%$. Based on the occupations, internet users were dominated by workers or entrepreneur with the total users of 82.2 million or around $62 \%$, then followed by housewives with the total users of 22 million or around $16.6 \%$, college students with 10.3 millions of users or around $7.8 \%$, students with 8.3 millions of users or around $6.3 \%$, and other miscellaneous occupations with the users of 796 thousands or around $0.6 \%$. Based on the data, it is found that the internet users for students and college students are still low [4].

Internet is the most widely discussed medium and has become a very important medium in developing other media [5]. Internet (Inter-Network) is a name for a computer network connecting the websites of academy, government, commerce, organization, and individual [6], internet is a global communication network connecting the whole computers worldwide despite the different operation systems and machines [7]. One of learning media using internet is e-learning by using moodle.

E-learning is the foundation and the logical consequence of today's development of information and communication technology. E-learning is a network for information and communication technology in learning and teaching [8]. In general, e-learning is the delivery of learning material through electronic media such as internet, internet/externet, satellite broadcast, audio/video tape, interactive TV, CD-ROM, and computer-based training (CBT) [9]. An example of e-learning development is moodle approach.

Moodle is a Learning Management System (LMS) designed to facilitate collaboration, based on online learning approach and finding [10]. Moodle is a webbased device that can be accessed through browser [11]. Moodle is a way toward an unlimited education, a pioneer that will build creativity and ideas [12]. Some learning activities that can use moodle are assignment, chat, forum, quiz and survey [13]. One of the reasons for the low learning outcome is the lack of learning media utilization. The optimal use of moodle is expected to improve students' learning outcome.

Based on the statement above, it can be known that internet is greatly influential to human being's lives, including the sector of education. Therefore, the aim of this research is to find out whether internet-based learning media using moodle approach can improve the quality of education. 


\section{RESEARCH METHODOLOGY}

The reason to have this literature study is to give insight about learning media using the approach of moodle to improve students' learning outcome. Many studies have contributed to this article. They were taken from twenty journals that were accessed through online websites related to the discussion of moodle. Some of them are Journal of Education for Business, Journal of Internet Technology, Journal of Mathematics, Science and Technology Education, Asian Journal Of Management Sciences \& Education, International Journal of Software Engineering and Its Applications, Journal of Education and Learning, Journal of Education and Learning, Journal of Education and Foreign Languages and Literature, Bio-Technology An Indian Journal, Journal of New Horizons in Education. The focus of this research is not only on the improvement of learning outcome caused by moodle, but also on the other findings. Those findings are then reflected in the form of a result.

The purpose of exploring, analysing and identifying several journals above is to make a whole conclusion from the journals that become the reference of the research. The use of moodle is expected to be able to give description of the future for stakeholders in education to improve the quality of education.

\section{RESULT}

The results of the literature study to the research related to moodle vary. The discussion about moodle in this study is based on the case study and literature study of international journals. However, there is a consistent finding, i.e. the use of moodle can improve the quality of education.

\section{Moodle Can Improve the Quality of Education}

Moodle (modular object-oriented dynamic learning environment) is a software platform that can be accessed freely that is developed as a medium in education world that can encourage interaction and collaboration [14]. By using moodle, a teacher can make learning material, quiz, electronic journal, etc. Students can also access it easily so that it can be more effective and efficient. It is in line with many experts who state that moodle has several main features such as survey, questionnaire, assignment, chat, forum, post, workshop, and also has the ability to create collaborative text [15]. A technology-based learning medium is designed by using moodle so that efficiency in teaching can be achieved [16]. There are eight factors that can influence the effectiveness of moodle viewed from students' perspective: intention, communication, format, information quality, performance result, benefit, satisfaction and system quality [17]. Moodle has great potential to become the centre of material collection so that it is easier for students to get the material [18]. In this way, the learning-teaching process can be improved. Moodle can improve the learning process [19]. In addition, Moodle can also improve students' learning outcome, motivation, communication, interest, discipline and confidence [14][15][20][21][22][23][24]. Both male and female students were satisfied to use moodle [25]. However, female students' satisfaction was higher than male students'. Moodle is effective to be used by teacher as a supporting medium for learning [26]. 
Moodle does not only give positive effect to the students but also to the teacher because by using moodle-based media teacher can monitor the students better and use it as a leaning medium at the same time [27][28].

Moodle becomes one of the ways to improve the effectiveness of learning. Some researchers have used moodle as a learning medium. Moodle has many pedagogic advantages because it can be used for learning approach that emphasizes on the knowledge building through active and interactive learning [29][30].

Using moodle in the learning process has been proven to improve the learning effectiveness because it can improve students' contribution in the learning activities. Moodle can not only create a more interactive and collaborative learning environment among students as the learning object but also can increase students' role because it can be used online [27]. It is in accordance with the goal of Indonesia's current curriculum 2013, i.e. to encourage students to be more active and innovative during the learning process.

Learning effectiveness refers to the final result of the teaching, including the change of knowledge, influence, and skill of students [31]. Today, relevant studies related to the digital learning have many indicators such as learning achievement and learning attitude, to evaluate the effectiveness of instruction mediated by computer [30][32][33].

Students' perceptions toward the use of moodle in education, i.e. moodle can make an effective and efficient learning, moodle can improve the education performance, moodle can give problem solution to the learning difficulties, moodle is easier to use, moodle is a good tool for education, moodle can be a simple way to improve education [27].

\section{Moodle Can Improve the Quality of Education In Indonesia}

Indonesia is a country with quite low level of education. It is proven by the survey result from Organization for Economic Co-operation and Development (OECD) in 2016 [1]. Indonesia was at $57^{\text {th }}$ of 65 countries under Malaysia and Singapore. One of the main problems was the fact that most of Indonesian teachers still used inefficient media. Good media can improve the students' learning outcome. It is known from the researches published in the research journals around the world. The researches in the journals can be related to the problem in Indonesia, that moodle can also be used to improve students' learning outcome. Media are components of education that are inseparable from learning and teaching process to gain the goal of education [3]. One of the media that can improve the effectiveness of education is moodle. Moodle is an effective way to improve education [34][35]. Moodle can improve students' motivation and achievement [20]. Therefore, schools in Indonesia can also develop internet-based media using moodle approach. Teachers and students should have a good understanding of internet so that this medium can be used to improve the quality of education in Indonesia.

\section{CONCLUSION AND RECOMMENDATION}

Education is a means to improve the quality of life. One of the components in education is learning media. A good learning medium is the one that can improve students' learning outcome, and furthermore can improve students' motivation and 
achievement. Based on the literature study from several educational research journals about moodle, it is found that education can be improved by using moodle. Moodle can be applied as a means to improve students' learning outcome, and Indonesia is not an exception. Besides, teachers should also be able to use internet-based media with Moodle approach to support the learning process so that students' learning outcome and quality of education in general can be improved.

\section{REFERENCES}

[1] Organisation for Economic Co-operation and Development (OECD). "Peringkat pendidikan Indonesia”. The Guardian. edupost.id. 28 April 2016.

[2] Sugandi, A. 2005. Teori Pembelajaran. Semarang: UNNES Press.

[3] Arsyad, A. 2011. Media Pembelajaran. Jakarta. Rajawali Pers

[4] Asosiasi Penyelenggara Jasa Internet Indonesia. 2016. "Data Pengguna Internet Indonesia tahun 2016". situs riset Internet Worlds Stats.

[5] Flew, T. 2005. "New media: an introduction (edisi kedua)". Oxford University Press

[6] Rohaya, S. 2008. INTERNET: Pengertian, Sejarah, Fasilitas dan Koneksi. Fihris Jurna l: EJournal. 3 (1). 1-16

[7] Ahmadi and Hermawan. 2013. E-Business \& E-Commerce. Yogyakarta. Penerbit Andi.

[8] Naidu, S. 2006. "E-Learning A Guidebook of Principles, Procedures and Practices". Commonwealth of Learning Media Centre for Asia. Australia

[9] Surjono, H. M. 2013. "Membangun Course E-Learning Berbasis Moodle”. Yogyakarta. UNY Press

[10] Cahir, J., M. McNeill, A. Bosanquet, and C. J, Trawoger. 2014. "Walking out the door: casualisation and implementing Moodle", International Journal of Educational Management. 28 (1). $5-14$

[11] Cole, J and H. Foster. 2008. "Using Moodle”. America. O'Reilly

[12] Ismanto, H. 2012. "Pembuatan Aplikasi Perkuliahan Jarak Jauh Berbasis Web Menggunakan Moodle pada Universitas Musamus Merauke”. Prosiding SNaPP2012: Sains, Teknologi, dan Kesehatan. 3 (1). 413-421.

[13] Rice, W. H. 2006. "Moodle-Learning Course Development, Complete Guide To Successful Learnig Using Moodle". Birmingham-Mumbai. Packt Publishing.

[14] Amandu, G. M., J. K. Muliira, and D. C. Fronda. 2013. "Using moodle e-learning platform to foster student self-directed learning: Experiences with utilization of the software in undergraduate nursing courses in a Middle Eastern university", Procedia Social and Behavioral Sciences. 93. 667-683.

[15] Domenico, E. B. L d., and C. R. Cohrs. 2016. "Moodle platform for the construction of knowledge in intensive care: an experimental study". Acta Paul Enferm. 29 (4). 381-389

[16] Chen, C. 2014. "Research on design of modern education technology course based on moodle platform". Bio Technology An Indian Journa. 10 (19). 11310-11316.

[17] Damnjanovic, V., S. Jednak, and I. Mijatovic. 2015. "Factors affecting the effectiveness and use of Moodle: students' perception". Interactive Learning Environments. 23 (4). 496-514.

[18] Costa, C., H. Alvelos, and L. Teixeira. 2012. "The use of Moodle e-learning platform: a study in a Portuguese University". Procedia Technology. 5 (2012). 334-343

[19] Caputi, V,. and A. Garrido. 2015. "Student-oriented planning of e-learning contents for Moodle". Journal of Network and Computer Applications. 4 (001). 1-27.

[20] Al-Ani., W. T. 2013. "Blended Learning Approach Using Moodle and Student's Achievement at Sultan Qaboos University in Oman", Journal of Education and Learning. 2 (3). pp. 96-110

[21] Lin, Y. W., C. L. Tseng. and P. J. Chiang. 2016. "The Effect of Blended Learning in Mathematics Course". EURASIA Journal of Mathematics, Science and Technology Education. 13 (3). 741-770.

[22] Siirak, V. 2008. "Moodle e-learning environment: An effective tool for a development of a learning culture". Institution of Chemical Engineers Symposium Series. 154. 290-296. 
[23] Chen, P. C., T. S. Lan, S. C. Chiu, and Y. H. Lan. 2014. "A Study of Investigating the Learning Effectiveness of Applying the MOODLE E-Learning in Taiwan's Elementary School”. Journal of Internet Technology. 14 (7). 1191-1194.

[24] Goyal, E., and S. Tamber. 2015. "Effectiveness Of Moodle-Enabled Blended Learning In Private Indian Business School Teaching Niche Programs". Journal of New Horizons in Education. 5 (2). 14-22.

[25] Horvat, A., M. Dobrota., M. Krsmanovic, and M. Cudanov. 2015. "Student perception of Moodle learning management system: a satisfaction and significance analysis". Interactive Learning Environments. 23 (4). 515-527.

[26] Wu, W. S. 2008. "The application of Moodle on an EFL collegiate writing environment". Journal of Education and Foreign Languages and Literature. V. (7). 45-56

[27] Tee, S. S., T. S. Mariam, T. Wook, and S. Zainudin. 2013. "User Testing for Moodle Application”. International Journal of Software Engineering and Its Applications. 7 (5). 243252.

[28] Zakaria, E., and M. Y. Daud. 2013. "The Role Of Technology: Moodle As A Teaching Tool In A Graduate Mathematics Education Course". Asian Journal Of Management Sciences \& Education. 2 (4). 146-152.

[29] Lu, J., and N. W. Y. Law. 2011. "Understanding collaborative learning behavior from Moodle log data". Interactive Learning Environments. 20 (5). 451-466

[30] White, B. 2010. "Using ICT to enhance curriculum opportunities for students in rural and remote schools". Australian Educational Computing. 25(2). 27-30.

[31] Piccoli, G., R. Ahmad, and B. Ives. 2001. "Web-based virtual learning environments: A research framework and a preliminary assessment of effectiveness in basic IT skills training". MIS Quarterly, 401-426.

[32] Chou, S. W., and C. H. Liu. 2005. "Learning effectiveness in a web-based virtual learning environment: A learner control perspective". Journal of Computer Assisted Learning, 21(1), 6576.

[33] DeTure, M. 2004. "Cognitive style and self-efficacy: Predicting student success in online distance education”. American Journal of Distance Education. 18(1). 21-38.

[34] Chung, C., and D. Ackerman. 2015. "Student Reactions to Classroom Management Technology: Learning Styles and Attitudes Toward Moodle". Journal of Education for Business. 90 (4). 217 223.

[35] Nedeva, V. 2005." The Possibilities Of E-Learning, Based On Moodle Software Platform”. Trakia Journal of Sciences. 3 (7). 12-19. 